\title{
ANALYSIS OF HYGROTHERMAL CONDITIONS OF EXTERNAL PARTITIONS IN AN UNDERGROUND FRUIT STORE
}

\author{
Grzegorz Nawalany', Paweł Sokołowski ${ }^{1}$
}

1 Department of Rural Building, University of Agriculture in Krakow, al. Mickiewicza 24/28, 30-059 Kraków, Poland, e-mail: g.nawalany@ur.krakow.pl; p.sokolowski@ur.krakow.pl

Received: 2016.06.07 Accepted: 2016.07 .29 Published: 2016.09 .20

\begin{abstract}
The paper presents the analysis of hygrothermal conditions of external partitions in an underground fruit store. The results of measurements of temperature and humidity of the indoor and outdoor air as well as the surface surrounding temperature and the temperature of the air surrounding the store constituted the boundary conditions for the hygrothermal calculations. The paper presents the calculation of the distribution of the temperature and humidity on the ground floor, the wall contacting the ground, the wall contacting the outside air, and the ceiling above the storage chamber. The heat and moisture calculations have shown high risk of condensation submerged in non-insulated external walls. The condition of the adaptation of a traditional cold store to a simple and atmosphere controlled cold one is to increase the thermal resistance of the partitions. Such a solution will let cut the energy demand in those types of agricultural buildings.
\end{abstract}

Keywords: fruit store, energy management, heat exchange, hygrothermal conditions of partitions

\section{INTRODUCTION}

The problem of fruit and vegetables storage is still the subject of research of many scientists around the world. The research in this respect focus primarily on the search for more and more effective, and at the same time more energy-efficient ways of their storage. In works devoted to the storage a lot of space is devoted to determine indicators that facilitate the assessment, prediction and management of crop's quality, both in the period of their storage and outside that period [Delaire et al. 2015, Harker et al. 1997, Siddiqui and Bangerth 1995, Palmer et al. 2010, Saei et al. 2011]. The ability to influence the quantitative and qualitative characteristics of stored vegetables and fruit are closely related to the appropriate regulation and ensuring optimum microclimate inside the storage facility and storage time [Marks 2011, Krzysztofik and Łapczyńska 2008]. A method of forming temperature and humidity conditions in storage facilities depends mainly on the type of the building. The greatest impact of the external climate on the internal conditions is observed in traditional storage buildings, which are cooled with cold external air via natural ventilation. In cold stores, the cooling effect of the external climate on the internal microclimate is smaller, thanks to the cooling system combined with mechanical ventilation of storage chamber. The most preferred solution, from the point of view of providing the best conditions for crop's storage, are cold stores with controlled atmosphere, in which it is possible to determine very precisely, not only the temperature and relative humidity of internal air, but also the gas composition and air movement in the storage chamber [Chądzyński and Piróg 2013]. The type of the used storage facility is associated with the adoption of appropriate material and design solutions of external partitions. Improperly designed partitions may significantly increase energy expenditure, incurred in order to ensure an adequate microclimate in the cold chamber [Janczarek 2010]. In terms of long-term use of the building it is very important to protect the external partitions from the damaging effects 
of moisture, and in particular against submerged condensation of water vapor [Radoń and Künzel 2006 Nawalany et al. 2015]. In storage buildings, the ground occurring beneath the building plays a very important role in shaping thermal conditions of partitions and internal microclimate, and in the case of earth-sheltered facilities also the ground adjacent to external walls [Radon et al. 2003 Nawalany et al. 2003]. Creation of suitable thermal and humidity conditions in external partitions of storage facilities depends primarily on the material and design solutions taken. The significance of this phenomenon may increase in the case of adaptation of traditional storages for cold stores.

\section{PURPOSE AND SCOPE OF WORK}

The aim of the study was to investigate the temperature and humidity conditions of partitions in traditional storage and in earth-sheltered fruit cold store.

The scope of the study included the creation of a calculation model and its validation based on the results of field studies. Using calculation model simulations were carried out for three calculation variants. Their results were subjected to comparative analysis.

\section{MATERIALS AND METHODS}

Field studies were carried out in a traditional fruit storage, located in the Małopolskie Voivodeship. During analyzed period, from October to May, it stored two varieties of apples: champion and golden delicious. The use of cooling units helped extend the storage time of fruit. The chamber used gravitational ventilation and humidification, by pouring the floor with water. The model used for calculation is presented in Figure 1.

For calculations of thermal and humidity conditions in external walls of the studied facility a WUFIplus computer software was used. The results of field tests were used to validate the calculation model. Validation of theoretical calculations showed very good agreement with the results of field tests. Validated model was used to perform calculations, based on the statistical climate for meteorological Kraków-Balice station. Calculation of 1-hour time step was assumed and the results were averaged for daily data. Table 1 summarizes the material and design solutions of external partitions adopted in the model.

Physical parameters of building materials used in temperature and humidity calculations of partitions were adopted on the basis of PN-EN ISO 6946 norm and are summarized in Table 2.

A detailed analysis of thermal and humidity conditions of partitions was conducted in terrestrial and earth-sheltered partitions.

Calculations of the distribution of temperature and moisture in partitions were conducted for a 1 year period, taking into account the division into storage period, lasting from October to May and into technological break, lasting from May to September.

\section{RESULTS AND ANALYSIS}

The Figures 2-4 show the course of temperature and relative humidity of internal and external air for three calculation variants under consideration.

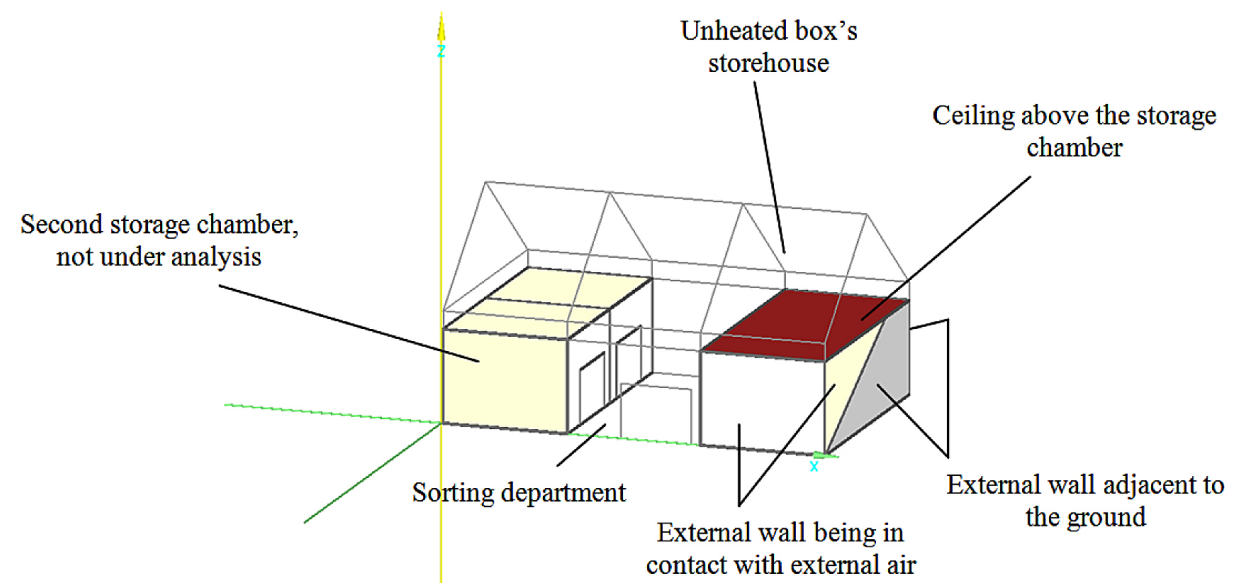

Figure 1. Calculation model generated in WUFI plus program 
Table 1. Basic technical assumptions adopted for the calculation conditions

\begin{tabular}{|c|c|c|c|}
\hline Assumptions & Variant I & Variant II & Variant III \\
\hline Type of facility & $\begin{array}{c}\text { traditional earth-sheltered } \\
\text { storage }\end{array}$ & $\begin{array}{c}\text { earth-sheltered storage with } \\
\text { thermal insulation of external } \\
\text { partitions }\end{array}$ & $\begin{array}{l}\text { earth-sheltered } \\
\text { cold store }\end{array}$ \\
\hline Ventilation & natural & natural & mechanical \\
\hline Cooling & no & no & yes \\
\hline $\begin{array}{l}\text { Temperature required inside } \\
\text { the object }\end{array}$ & \multicolumn{3}{|c|}{$0-3^{\circ} \mathrm{C}$} \\
\hline External walls construction & $24 \mathrm{~cm}$ cider-concrete block & $\begin{array}{c}10 \mathrm{~cm} \text { XPS styrofoam, } \\
24 \mathrm{~cm} \text { cider-concrete block }\end{array}$ & $\begin{array}{c}10 \mathrm{~cm} \text { XPS styrofoam, } \\
24 \mathrm{~cm} \text { cider-concrete block }\end{array}$ \\
\hline $\begin{array}{l}\text { Construction of walls adjacent } \\
\text { to the ground }\end{array}$ & $\begin{array}{l}24 \mathrm{~cm} \text { cider-concrete block, } \\
\text { PCV moisture-proof isolation }\end{array}$ & $\begin{array}{l}10 \mathrm{~cm} \text { XPS styrofoam, } \\
24 \mathrm{~cm} \text { cider-concrete block, } \\
\text { PCV moisture-proof isolation }\end{array}$ & $\begin{array}{c}10 \mathrm{~cm} \text { XPS styrofoam, } \\
24 \mathrm{~cm} \text { cider-concrete block, } \\
\text { PCV moisture-proof isolation }\end{array}$ \\
\hline $\begin{array}{l}\text { Construction of the floor on } \\
\text { the ground }\end{array}$ & $\begin{array}{c}10 \mathrm{~cm} \text { cement screed, } \\
\text { PCV moisture-proof insulation, } \\
10 \mathrm{~cm} \mathrm{C} 12 / 15 \text { concrete, } \\
30 \mathrm{~cm} \text { sandy gravel }\end{array}$ & $\begin{array}{c}10 \mathrm{~cm} \text { cement screed, } \\
\text { PCV moisture-proof insulation, } \\
10 \mathrm{~cm} \text { C } 12 / 15 \text { concrete, } \\
30 \mathrm{~cm} \text { sandy gravel } \\
\end{array}$ & 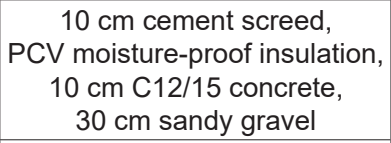 \\
\hline $\begin{array}{l}\text { Construction of the ceiling } \\
\text { above the storage chamber }\end{array}$ & $\begin{array}{c}20 \mathrm{~cm} \text { monolithic reinforced } \\
\text { concrete slab }\end{array}$ & $\begin{array}{c}20 \mathrm{~cm} \text { monolithic reinforced } \\
\text { concrete slab, } \\
10 \mathrm{~cm} \text { XPS styrofoam }\end{array}$ & $\begin{array}{c}20 \mathrm{~cm} \text { monolithic reinforced } \\
\text { concrete slab, } \\
10 \mathrm{~cm} \text { XPS styrofoam }\end{array}$ \\
\hline
\end{tabular}

Table 2. Technical characteristics of materials used in theoretical calculations

\begin{tabular}{|c|c|c|c|c|c|}
\hline \multirow{2}{*}{ No. } & \multirow{2}{*}{ Building material } & $\rho$ & c & $\lambda$ & Thickness \\
\hline & & {$\left[\mathrm{kg} \cdot \mathrm{m}^{-3}\right]$} & {$\left[\mathrm{J} \cdot \mathrm{kg}^{-1} \cdot \mathrm{K}^{-1}\right]$} & {$\left[\mathrm{W} \cdot \mathrm{m}^{-1} \cdot \mathrm{K}^{-1}\right]$} & {$[\mathrm{m}]$} \\
\hline 1 & Cider-concrete block & 1100 & 840 & 0.63 & 0.240 \\
\hline 2 & PCV moisture-proof insulation & 1000 & 1500 & 0.16 & 0.001 \\
\hline 3 & Concrete & 2220 & 850 & 1.60 & $0.100-0.250$ \\
\hline 4 & XPS styrofoam & 40 & 1500 & 0.03 & 0.100 \\
\hline 5 & Sand bed under the floor on the ground & 1579 & 850 & 0.50 & 0.300 \\
\hline
\end{tabular}
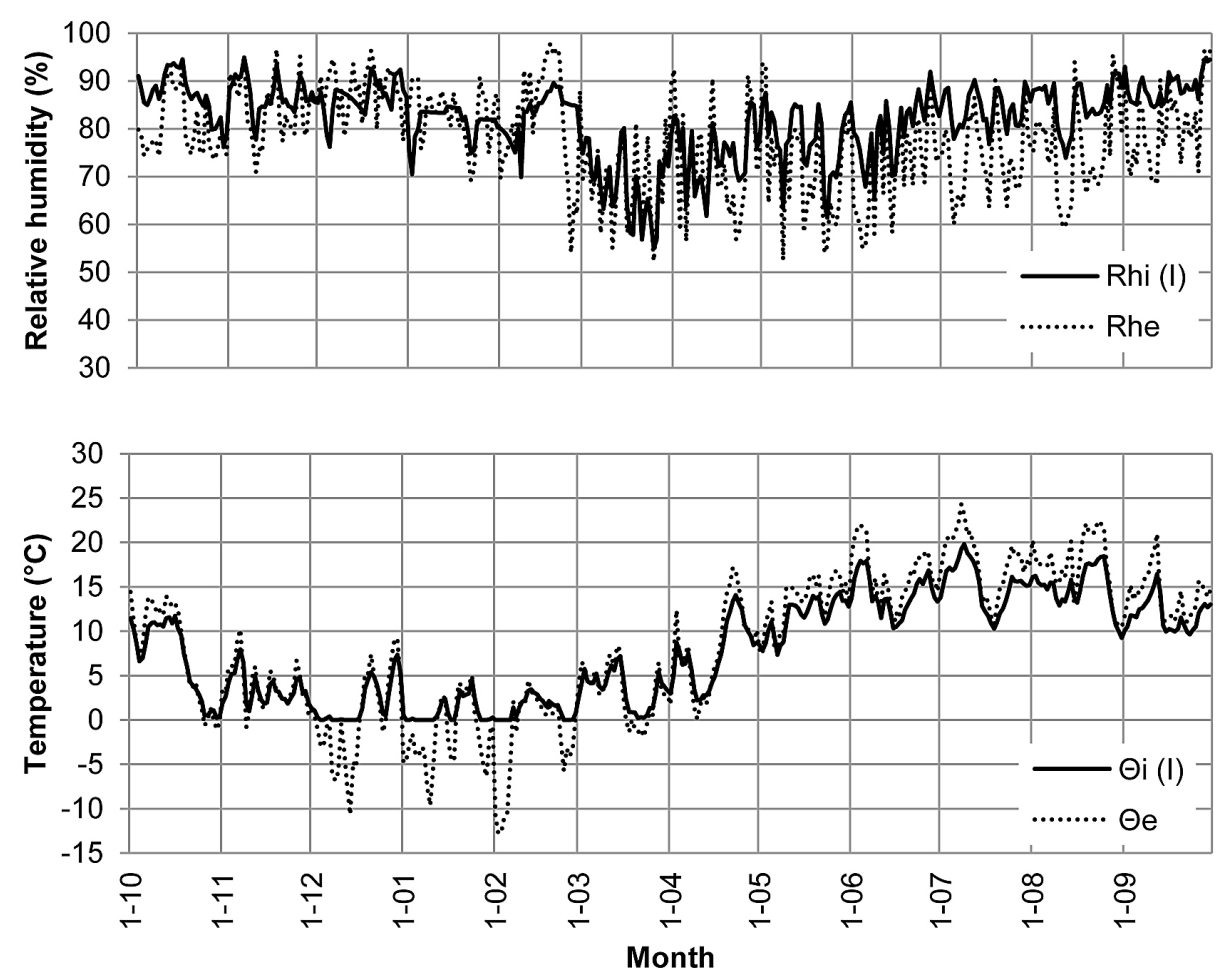

Figure 2. The course of internal air temperature $\left(\Theta_{i}\right)$ against external air temperature $\left(\Theta_{e}\right)$ and relative humidity of internal $\left(\mathrm{Rh}_{\mathrm{i}}\right)$ and external air $(\mathrm{Rh})$ for variant $\mathrm{I}$ 

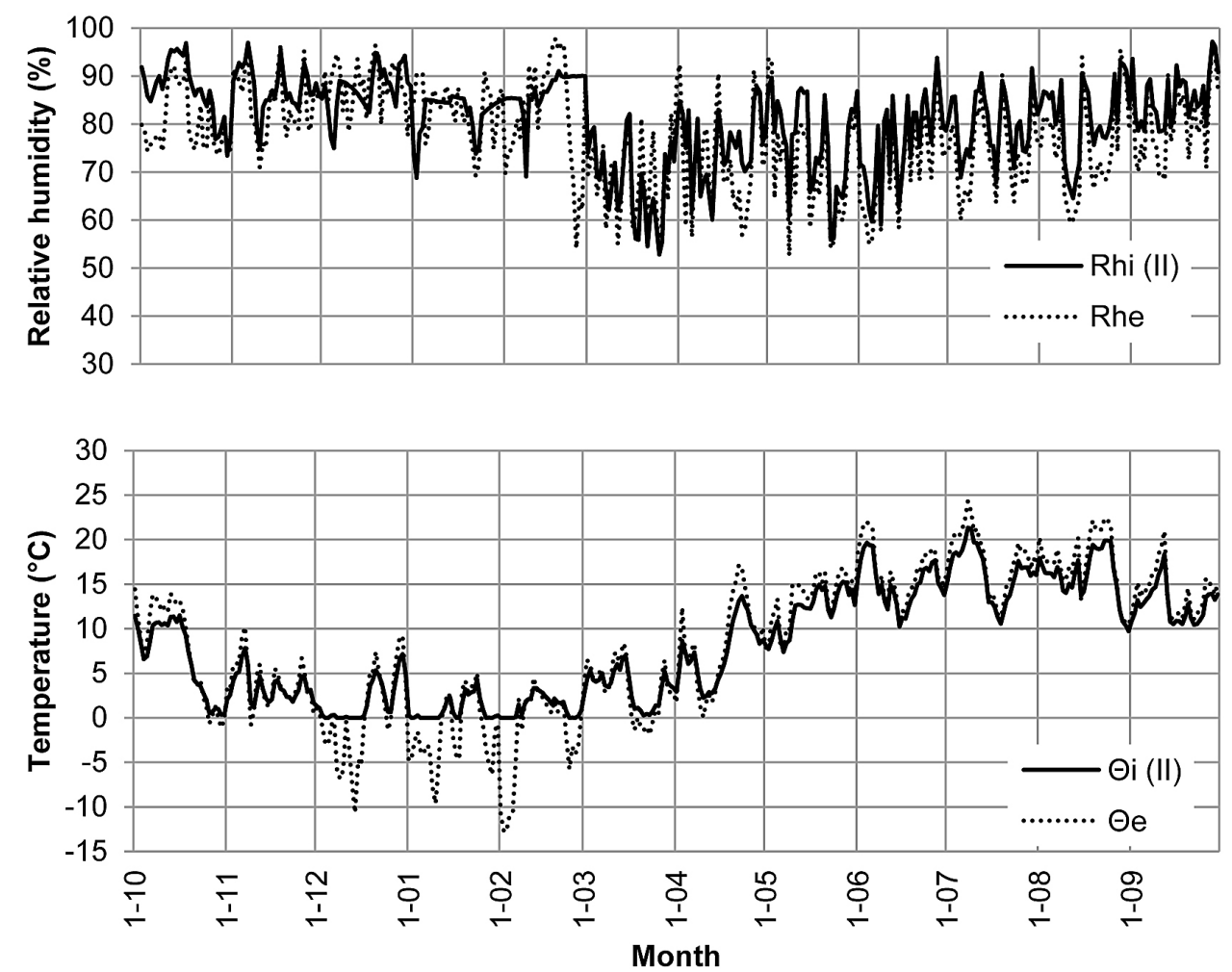

Figure 3. The course of internal air temperature $\left(\Theta_{\mathrm{i}}\right)$ against external air temperature $\left(\Theta_{\mathrm{e}}\right)$ and relative humidity of internal $\left(\mathrm{Rh}_{\mathrm{i}}\right)$ and external air $\left(\mathrm{Rh} \mathrm{e}_{\mathrm{e}}\right)$ for variant II
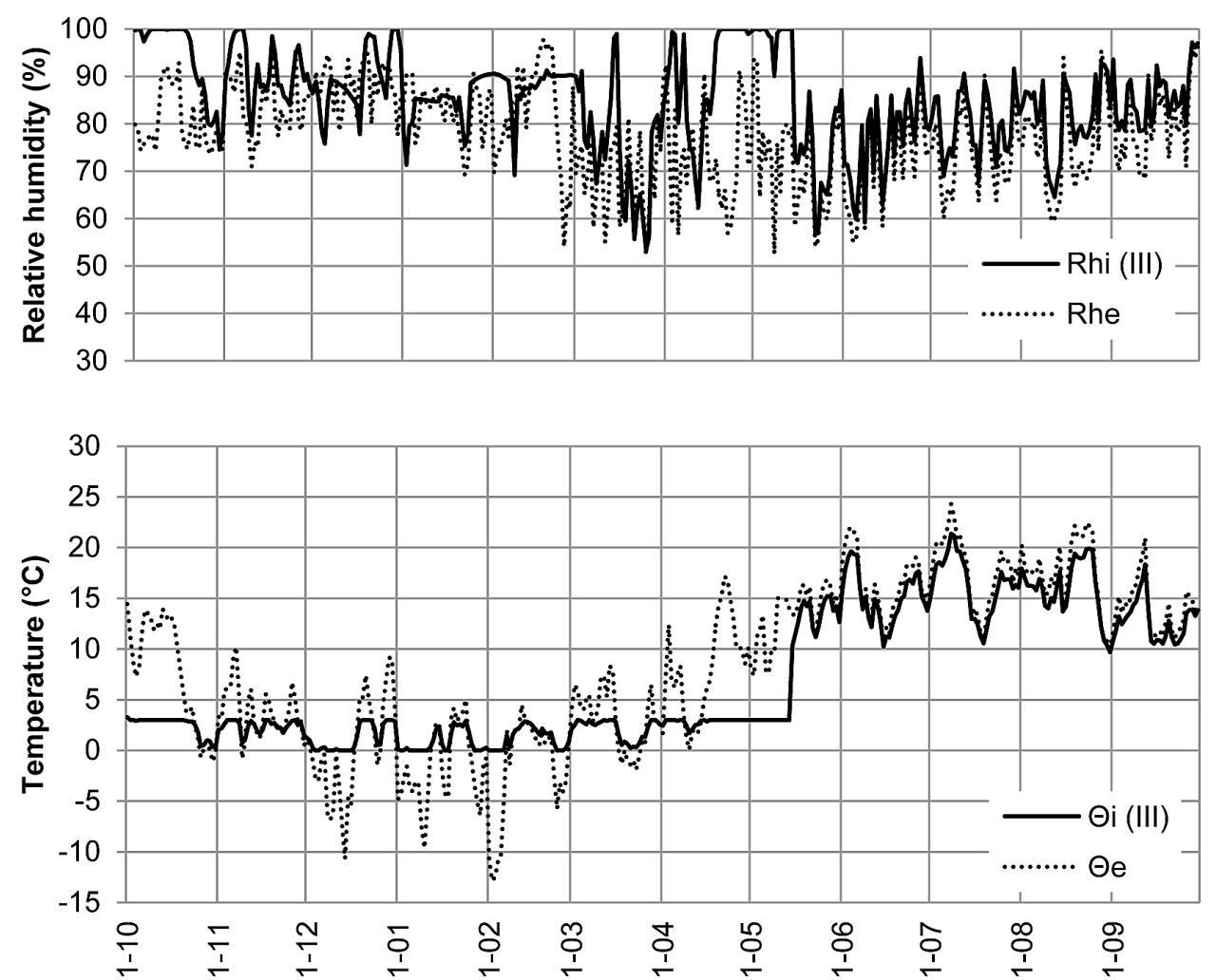

Figure 4. The course of internal air temperature $\left(\Theta_{i}\right)$ against external air temperature $\left(\Theta_{e}\right)$ and relative humidity of internal $\left(\mathrm{Rh}_{\mathrm{i}}\right)$ and external air $(\mathrm{Rh})$ for variant III 
In traditional storage, where partitions did not have thermal insulation (variant I), and in traditional storage, in which thermal insulation was applied (variant II) an external climate had a large influence on the creation of internal microclimate. In the second calculation variant the application of thermal insulation during storage period (October-May) had no significant effect on the change in temperature inside the storage chamber. During technological break (June-September), the average daily temperature inside the chamber was higher by approx. $1{ }^{\circ} \mathrm{C}$ in storage, which used thermal insulation of partitions. The application of cooling (variant III) resulted in stabilization of internal air temperature at the level of $0-3^{\circ} \mathrm{C}$ for a storage period. Cooling of air in the chamber resulted in increased average daily values of internal air relative humidity in relation to other variants. This contributed to an increase in the risk of condensation of moisture on the internal surfaces of partitions. During technological break the variability of temperature and humidity parameters of internal air for all three calculation variants followed a similar pattern.

The results of calculation analysis showed a strong influence of the ground occurring beneath the building on thermal stabilization of the floor. During storage period water was poured on storage floor in order to provide the required relative humidity inside the chamber. During technological break the concrete floor in the chamber dried out. The average surface temperature of the floor during storage period was in the range of $1.0-3.4^{\circ} \mathrm{C}$ in variant III (cooling chamber). In variants I and II was respectively of $1.3-6.9^{\circ} \mathrm{C}$ and $1.2-6.8^{\circ} \mathrm{C}$.

The results of detailed thermal and humidity analysis of external wall that was in contact with external air are shown in Figures 5 and 6.

The results of thermal and humidity analysis of external wall that was in contact with external air showed that in the period from December to March there occurs a cyclical freezing and thaw-
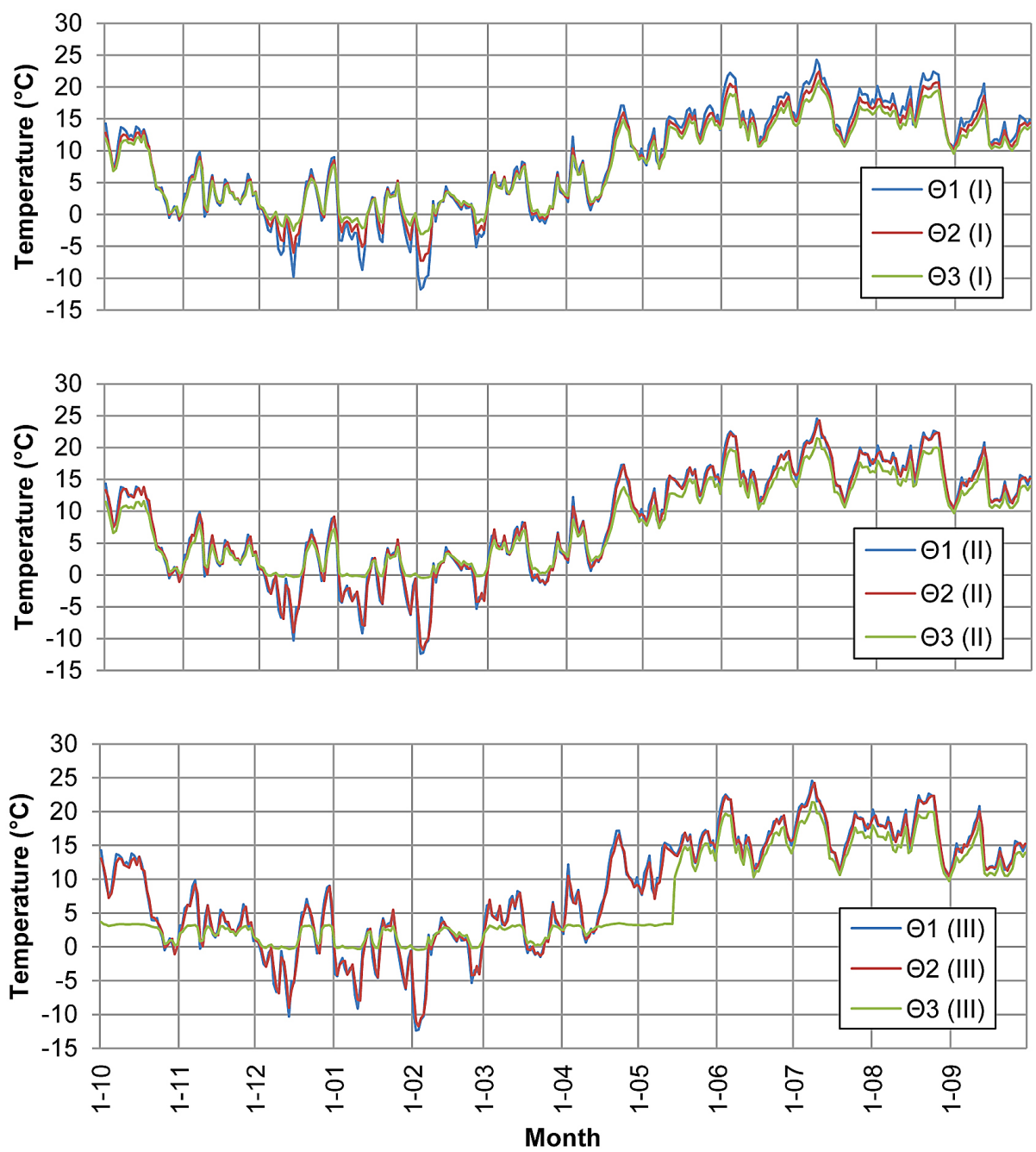

Figure 5. The course of temperature on the external $\left(\Theta_{1(\mathrm{I})}, \Theta_{1(\mathrm{II})}, \Theta_{1(\mathrm{III})}\right)$ and internal $\left(\Theta_{3(\mathrm{I})}, \Theta_{3(\mathrm{III}}, \Theta_{3(\mathrm{III})}\right)$ wall surface and on the axis of partition's construction layer $\left(\Theta_{2(\mathrm{I})}, \Theta_{2(\mathrm{III})}, \Theta_{2(\mathrm{III})}\right)$ : a) variant I, b) variant II, c) variant III 

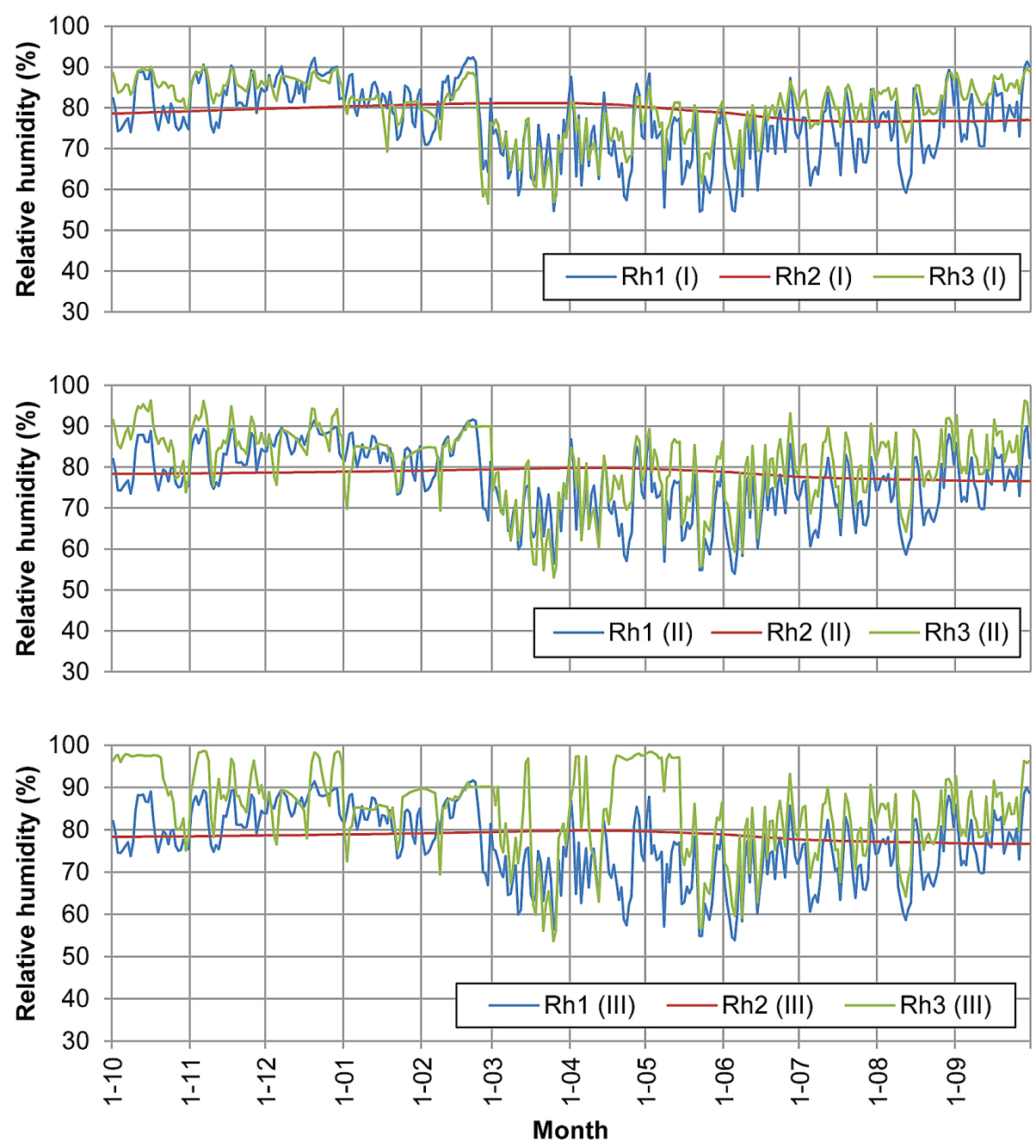

Figure 6. The course of relative humidity on the external $\left(\mathrm{Rh}_{1(\mathrm{I})}, \mathrm{Rh}_{1(\mathrm{II})}, \mathrm{Rh}_{1(\mathrm{III})}\right)$ and internal $\left(\mathrm{Rh}_{3(\mathrm{I})}, \mathrm{Rh}_{3(\mathrm{II})}, \mathrm{Rh}_{3(\mathrm{III})}\right)$ wall surface and on the axis of partition's construction layer $\left(\mathrm{Rh}_{2(\mathrm{I})}, \mathrm{Rh}_{2(\mathrm{II})}, \mathrm{Rh}_{2(\mathrm{III})}\right):$ a) variant I, b) variant II, c) variant III

ing of partition throughout the whole cross-section. The observed phenomenon may affect the durability and deterioration of partition's technical parameters, as a result of its accelerated destruction process. The application of thermal insulation on internal surface of external wall, that was in contact with the air during winter, causes the risk of freezing of partition throughout its cross-section. In variants II and III, the internal overhead wall surface temperature values were above $0^{\circ} \mathrm{C}$ throughout the whole tested period. During storage period the insulation layer contributed to a drop in relative humidity in this partition by approx. 2\% (Figure 7)

Partitions being in contact with the ground are characterized, in terms of temperature and humidity aspects, with a big impact of this facility. In none of tested variants no freezing process was observed in partitions being in contact with the ground. The application of thermal insula- tion on the inside contributed to an increase in temperature of wall's internal surface by an average of $1.5^{\circ} \mathrm{C}$ for storage period and by $7^{\circ} \mathrm{C}$ for technological break.

The course of average monthly relative humidity values in the wall adjacent to the ground depending on the adopted variant is shown in Figure 8.

The results of comparative analysis of tested variants, in terms of the application of thermal insulation, have shown that the application of thermal insulation on construction wall's internal surface being in contact with the ground, contributes to a decrease in relative humidity in tested partition by an average of $5-8 \%$. The calculation results showed that outside the storage period, in terrestrial partitions, a decrease in relative humidity, regardless of any thermal insulation is observed. In partitions being in contact with the ground no reduction of relative humidity value outside the storage period was observed. 
$\square R h 2$ (I) $\quad \square R h 2($ II) $\quad \square R h 2$ (III)

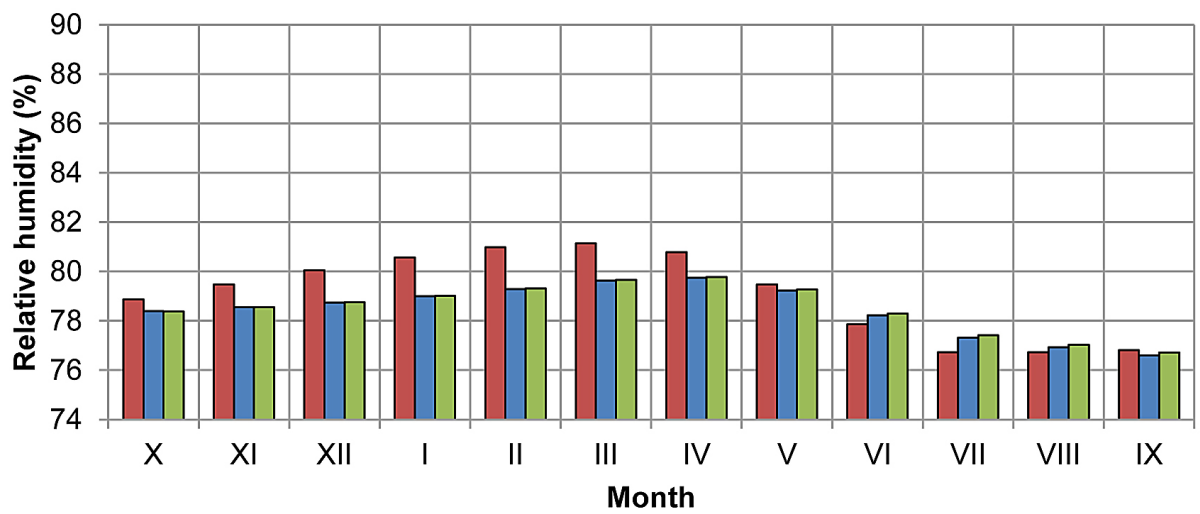

Figure 7. A comparison of average monthly relative humidity values $\left(\mathrm{Rh}_{2}-\right.$ variant $\mathrm{I}, \mathrm{Rh}_{2(\mathrm{I})}-$ variant II, $\mathrm{Rh}_{2(\mathrm{AC})}$ - variant III) in storage's construction wall (terrestrial partition)

$\square R h 2$ (I) $\quad \square R h 2$ (II) $\quad \square R h 2$ (III)

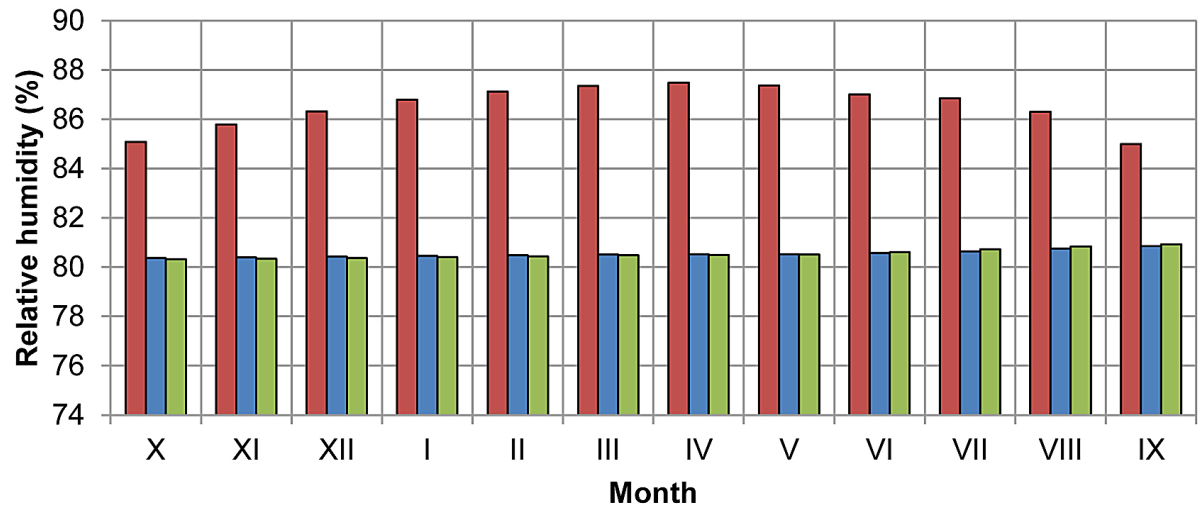

Figure 8. A comparison of average monthly relative humidity values $\left(\mathrm{Rh}_{2}-\right.$ variant $\mathrm{I}, \mathrm{Rh}_{2(\mathrm{I})}-$ variant II, $\mathrm{Rh}_{2(\mathrm{AC})}$ - variant III) in storage's construction wall (underground partition)

The application of ceiling thermal insulation located between the cooling chamber and unheated box's storehouse, contributed to the reduction of the risk of condensation of water vapor on its internal surface. In the period from October to May, the average temperature in the whole cross-section of the ceiling ranged from $0.8-7.3{ }^{\circ} \mathrm{C}$ and the relative humidity ranged from $70 \%$ to $86 \%$ (variant I). Variants 2 and 3 showed an increase in the temperature difference between the internal and the external surface of the ceiling, which was approx. $3^{\circ} \mathrm{C}$ (variant II) and $5{ }^{\circ} \mathrm{C}$ (variant III).

\section{CONCLUSIONS}

1. In traditional fruit storage the temperature in walls from terrestrial part of chambers ranged from -6 to $22{ }^{\circ} \mathrm{C}$, whereas in partitions being in contact with the ground from 2 to $12{ }^{\circ} \mathrm{C}$.
2. The adaptation of traditional storage for cold store and the application of thermal insulation in chambers' partitions resulted in a increase in temperature variation in walls from terrestrial part $\left(-12\right.$ to $\left.20^{\circ} \mathrm{C}\right)$.

3. The storage facilities equipped with active cooling system allow favorable and stable thermal conditions for stored products but in winter period the temperature in whole cross-section of walls from terrestrial part fell below $0{ }^{\circ} \mathrm{C}$.

4. The application of thermal insulation on the internal surface of walls being in contact with the ground does not cause an increased risk of partition's freezing.

5. The application of thermal insulation on the internal side of the partition contributes to an increased risk of moisture, which may result in a reduction in partition's durability due to the transfer of freezing zone and water vapor condensation inside the partition. 


\section{REFERENCES}

1. Chądzyński A., Piróg M. 2013. Obiekty do przechowywania owoców, warzyw lub ziemniaków. Budownictwo i Architektura, 12(3), 7-12.

2. Delaire M., Fatoumata S., Mehinagic E., Guillermin P., Patron C., Meurlay D., Morvan C. Symoneaux R. 2015. Effect of apple growth pattern on fruit textural quality at harvest and after cold storage in cv. 'Braeburn'. Scienta Horticulturae, 194, 14 October, 134-137.

3. Harker F.R., Redgwell R.J., Hallett I.C., Murray S.H., Carter G. 1997. Texture of fresh fruit. Horticultural Reviews, Wiley-Blackwell, Oxford, UK.

4. Janczarek M. 2010. Efekty energetyczne uzyskane na podstawie badań procesów cieplnych w przechowalniach $\mathrm{w}$ regionie lubelskim. Postępy Nauki i Techniki, nr 5, 124-131.

5. Krzysztofik B., Łapczyńska-Kordon B. 2008. Wpływ sposobów i czasu przechowywania na wybrane cechy sensoryczne jabłek. Inżynieria Rolnicza. R. 12, nr 2(100), 121-128.

6. Marks N. 2011. Wpływ mikroklimatu przechowalni na jakościowe i ilościowe wskaźniki i cechy jabłek. Inżynieria Rolnicza, 15(5), 171-177.

7. Nawalany G., Bieda W., Radoń J. 2003. Rozkład temperatury w gruncie w otoczeniu zagłębionej chłodni owoców. Acta Scientarum Polonorum. Formatio Circumiectus, 2(2), 117-128.
8. Nawalany G., Sokołowski P., Herbut P., Angrecka S. 2015. Charakterystyka cieplno-wilgotnościowa termomodernizowanych przegród w budynkach mieszkalnych na wybranym przykładzie. Infrastruktura i Ekologia Terenów Wiejskich, Nr IV/1, 887-898.

9. Palmer J.W., Harker F.R., Tustin D.S., Johnston J. 2010. Fruit dry matter concentration: a new quality metric for apples. Journal of the Science of Food and Agriculture., 90, 2586-2594.

10. PN-EN ISO 6946, 2008. Opór cieplny i wskaźniki przenikania ciepła. Metoda obliczeń. PKN, Warszawa.

11. Radoń J., Bieda W., Nawalany G. 2003. Effect of depth and insulation of a fruit cold storage plant floor on heat Exchange with the Grodnu. Electronic Journal of Polish Agricultural Universities, 6(1).

12. Radoń J., Künzel H. 2006. Problemy cieplno-wilgotnościowe przy renowacji ścian budynków z muru pruskiego. Acta Scientiarum Polonorum: Architectura 5(1), 45-53.

13. Saei A., Tustin D.S., Zamani Z., Talaie A., Hall A.J. 2011. Cropping effects on the loss of apple fruit firmness during storage: the relationship between texture retention and fruit dry matter concentration. Scienta Horticulturae, 130, 256-265.

14. Siddiqui S., Bangerth F. 1995. Effect of preharvest application of calcium on flesh firmness and cellwall composition of apples - influence of fruit size. Journal of Horticultural Science, 70, 263-266. 